v. 7, n.2

Vitória-ES, May - Aug . 2010

p. 37 - $59 \quad$ ISSN $1808-2386$

DOI: http://dx.doi.org/10.15728/bbr.2010.7.2.3

\title{
Working capital, profitability, liquidity and solvency of healthcare insurance companies
}

\author{
André Luiz de Souza Guimarães ${ }^{\dagger}$ \\ BNDES \\ Valcemiro Nossa ${ }^{\Omega}$ \\ Fucape Business School - FUCAPE
}

\begin{abstract}
SUMMARY: The purpose of this study is to analyze the adequacy of a working capital management normative model, in terms of profitability, liquidity and solvency. Through an empirical and analytical research, the analysis of variance results (ANOVA) of a sample containing financial information from 621 healthcare insurance companies for the year 2006, show that different working capital structures are associated with different levels of profitability, liquidity and solvency, suggesting a preference order different from the one theorized by Fleuriet / Braga. The results indicate that a certain structure - where financial current assets exceed onerous current liabilities, and cyclical current assets exceed cyclical current liabilities - is associated with higher levels of profitability, liquidity and solvency. In addition, the study reiterates the importance of efficient management of working capital to the performance and survival of healthcare insurance companies.
\end{abstract}

keywords: Working capital, profitability, solvency; healthcare, Fleuriet Model

Received in 10/23/2010; revised in 02/01/2010; accept in 04/20/2010.

Corresponding authors*:

† Doctor in Business Administration, Lubin School of Management, Pace University

$\Omega$ Doctor in Controllership \& Accounting Universidade de São Paulo.

Afiliation: Administrator at Brazilian Development Bank BNDES

Afiliation: Professor at Fucape Business School

Address: Rua Marquesa de Santos, no. 53, apto. 1503,

Address: Av. Fernando Ferrari, 1358, Boa Vista, Vitória - ES

Rio de Janeiro, RJ - Brazil CEP 22221-080

Email: alsguimaraes@gmail.com

- Brazil, CEP 29075-505.

Email: valcemiro@fucape.br

Telephone: (27) 4009-4444

Telephone: (21) 2172-8538

Fax: (27)4009-4432

Editor's note: This paper was accepted by Antonio Lopo Martinez 


\section{INTRODUCTION}

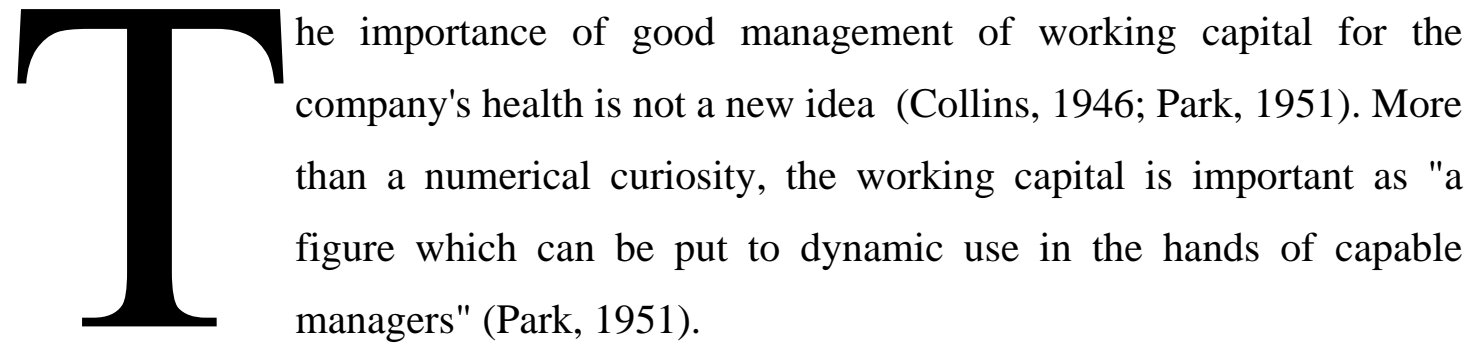

The proper management of working capital becomes extremely important when the company's business is to provide medical care. In this particular case, the bankruptcy of a company as a provider of health plan or hospital, for example, can cause irreversible damage to patients and significant damage along the care chain (Howard, 1995). Considering the strong increase in healthcare costs worldwide and the growing pressure on providers of medical care (Freudenheim, 2006), it seems prudent to pay attention to the financial health of these companies.

One of the key indicators of the companies' financial health is working capital (Altman, 1968). The framework discussed here - often called Fleuriet model (MF) - was introduced more than thirty years ago at Fundação Dom Cabral, by Fleuriet, Kehdy and Blanc (1978) as a new method for the dynamic and operational management of working capital.

Since its introduction, the MF became popular in Brazil, have being largely taught especially in accounting and management graduation and post-graduation courses (Brasil, 2003; Medeiros, 2005). Despite the longevity, except in Brazil and France (Fleuriet, 2005), there is no literature record for the use of the model in other countries.

The purpose of this article is to empirically examine the adequacy of a normative model, proposed by Fleuriet, Kehdy and Blanc $(1978,2003)$ and the type of working capital financing structures (Braga, 1991; Marques e Braga, 1995), in terms of profitability , liquidity and solvency. For this, the article is divided into six sections. Following this introduction, a brief review of the theory introduces the studied hypotheses.

The third section presents the methodology, describing the sample, variables, and methods of analysis used. The fourth section presents the results of the analysis, and is followed by a discussion of the results, which offers a review of interpretations of the attractiveness of the types of working capital financing structures in the Fleuriet model, and suggests a subdivision of types that might be useful in explaining the discrepancies between 
the theory and our empirical findings (Fleuriet, Kehdy e Blanc, 1978; Braga, 1991; Marques e Braga, 1995).

The final section summarizes the study, underlining the importance of an efficient management of working capital for the company's health, and outlines some directions for future studies.

\section{THEORY AND HYPOTHESES}

The Fleuriet Model is based on the existence of three interrelated cycles: production cycle, economic cycle and financial cycle. Therefore, every industry observes a characteristic financial cycle which indicates the normal rate at which transactions occur in that industry.

The financial cycle is also known as the cash conversion cycle (Richards e Laughlin, 1980) and represents the time it takes the company to recoup their investments (Gitman, 2004), indicating when and how much capital is needed to finance the operation. For example, a manufacture can have its cash conversion cycle starting with the payment of raw materials suppliers and ending with the receipt of sales.

Healthcare insurance, unlike most sectors of the economy, are mostly prepaid business (Alves, 2008), observing a favorable financial cycle, in which there is the anticipated payment of monthly premium rates and future payment of health care costs. Given this characteristic of the sector, a high balance of accounts receivable (e.g., more than 60 days) requires attention (e.g., possibly indicating an unrealistic balance of accounts receivable).

Also, a high balance of payables (e.g., more than 90 days) may suggest problems (e.g., suppliers and providers of care payment delay) that may lead to denying coverage for patients who need care. In normal conditions, health insurers experience a small (i.e., measured in days) negative financial cycle (i.e., collections and receipts occur more quickly than payments).

In 1978, Fleuriet and his co-authors published in Brazil his model of "Análise Dinâmica ou Avançada do Capital de Giro” (Dynamic or Advanced Analysis of Working Capital) (Fleuriet, Kehdy e Blanc, 1978), introducing and integrating two concepts that later and independently, become popular in the finance literature: the cash conversion cle (Richards e Laughlin, 1980) and the net liquid balance (or NLB) (Shulman e Cox, 1985; Shulman e Dambolena, 1986). 
Recently, these two concepts have been reintegrated in the Kiernan modified cash conversion cycle (1999). In his dynamic model, Fleuriet, Kehdy and Blanc (1978) noted that among the short-term obligations of the company, some are due to loans and financing, while other obligations are more directly related to the operation of the company, resulting from transactions with customers and suppliers.

The Fleuriet model (Fleuriet, Kehdy e Blanc, 1978) begins with a reclassification of the balance accounts in: short-term (or erratic), operating (or cyclical) and long term, as described in Table 1.

Table 1 - Reclassification of accounts according the Fleuriet model:

\begin{tabular}{l|l|l|l}
\hline Term & Reclassification & Assets & Liabilities \\
\hline Short & $\begin{array}{l}\text { Financial or } \\
\text { Erratic }\end{array}$ & $\begin{array}{l}\text { Financial accounts of current assets } \\
\text { (e.g., cash and net investment) }\end{array}$ & $\begin{array}{l}\text { Financial accounts of current } \\
\text { liabilities (e.g., loans) }\end{array}$ \\
\hline Short & $\begin{array}{l}\text { Operating or } \\
\text { Cyclical }\end{array}$ & $\begin{array}{l}\text { Operating accounts of current assets } \\
\text { (e.g., inventory, accounts receivable, } \\
\text { etc.) }\end{array}$ & $\begin{array}{l}\text { Operating accounts of current } \\
\text { liabilities (e.g., suppliers, } \\
\text { wages payable, etc.) }\end{array}$ \\
\hline Long & Permanent & Fixed and long-term assets & $\begin{array}{l}\text { Long-term liability and } \\
\text { stockholders1 equity }\end{array}$ \\
\hline
\end{tabular}

Source: adaptation of Fleuriet, Kehdy and Blanc (1978)

The first group, named "short term" or "erratic", includes accounts of a financial nature, such as cash and other equivalents investments (i. e. financial current assets) and loans or other financial obligations (i. e., onerous current liabilities). The second group, named "operating" or "cyclical" includes assets and liabilities not included in the first group.

Finally, the third group contains long-term accounts (i.e., non-current), such as fixed assets, long-term bonds and stockholder's equity. Following this reclassification, and according the nature of the sources and funds applications, three totals are calculated that determine the company's financial structure and liquidity under an operating point of view.

The first is the cash balance (ST), which represents the difference between applications and the short term sources and is calculated by subtracting onerous current liabilities (PCO) from financial current assets (ACF): ST = ACF - PCO. The cash balance indicates the actual liquidity of the company.

A positive cash balance indicates that the company has enough cash to cope with their short-term financial obligations without reducing the resources allocated to the operating cycle. A negative cash balance indicates that the company will have to obtain additional working capital or reduce the resources used in operational cycle in order to cope with shortterm financial obligations. 
The second total represents the working capital necessity (NCG), and is obtained by subtracting cyclical current liabilities (PCC) from cyclical current assets (ACC): NCG = ACC - PCC, or the difference between sources and applications of operating resources. The third total is working capital (CDG), be obtained by deducting current liabilities (PC) in current assets (AC): $\mathrm{CDG}=\mathrm{AC}-\mathrm{PC}$.

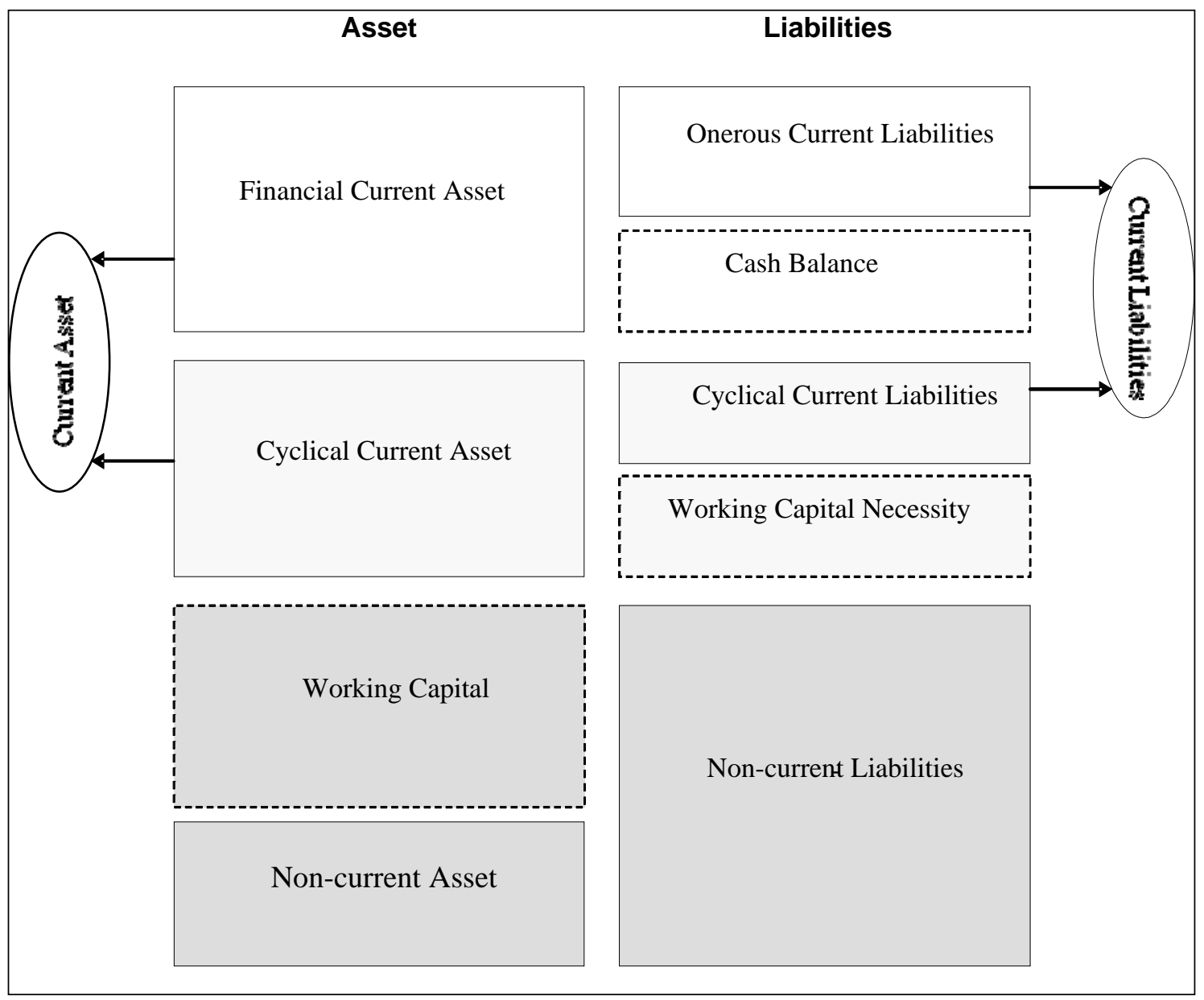

Image 1 - Graphic Summary of working capital in Fleuriet model Source: Prepared by the authors

This is equivalent to subtracting non-current assets (ANC) from non-current liabilities (PNC): CDG = PNC - ANC, since the difference between sources and applications is numerically equivalent to working capital.

Together, these three variables (i.e., CDG, ST, and NCG) form an accounting identity, in which the working capital (CDG) equals the sum of the cash balance (ST) and the needs of working capital (NCG): CDG = ST + NCG. Observe that variables can e negative or positive, depending on their behavior as a source or resources application.

This new identity reflects an accounting equilibrium on a financial point of view, in which the dynamics determines the way the firm finances its working capital, producing BBR, Braz. Bus. Rev. (Engl. ed., Online), 
different structures for financing working capital that reflect different equilibrium positions between sources and uses of short and long term funds. Fleuriet, Kehdy and Blanc (1978) highlighted four types of financial structures. Later, Braga (1991) showed that there were two more types (according to Table 2 and Image 2), resulting in a total of six types.

The four types of financial structure pointed by Fleuriet and his co-authors were orderable by financial strength or attractiveness (e.g., from best to worst), with each new type showing some deterioration in the financial structure. This direct correspondence no longer exists, since types V and VI pointed out by Braga (1991) were not as undesirable as Fleruiet’s type IV.

Marques and Braga (1995), on the other hand, reaffirm the financial strength or attractiveness for each kind of working capital financing structure (see Table 2).

Table 2 - Types of financing structure and company's financial status

\begin{tabular}{l|l|l|l|l}
\hline \multicolumn{1}{c|}{ Type } & \multicolumn{1}{c}{$\begin{array}{c}\text { Working capital } \\
\text { (CDG) }\end{array}$} & $\begin{array}{c}\text { Working capital } \\
\text { Necessity (NCG) }\end{array}$ & Cash Balance (ST) & Financial Status \\
\hline I & + & - & + & Excellent \\
II & + & + & + & Strong \\
III & + & + & - & Insufficient \\
\hline IV & - & + & - & Bad \\
V & - & - & - & Very Bad \\
VI & - & - & + & High Risk \\
\hline
\end{tabular}

Keys: + indicates positive values (in this study, higher or equal to zero) - indicates negative values Source: Reproduced from Marques \& Braga (1995)

The type I structure is seen as the strongest and most desirable (Braga, 1991; Marques e Braga, 1995). Type I observes positive working capital (i.e.: CDG $\geq 0$ ) and better liquidity than the other five structures, with financial current assets (ACF) exceeding onerous current liabilities (PCO) (i.e., ACF $\geq$ PCO, or ST $\geq 0$ ), more than compensating the fact that cyclical current liabilities exceed cyclical current assets (i.e., PCC $\geq$ ACC, or NCG $<0$ ). Type II is described as a solid structure (Braga, 1991; Marques e Braga, 1995).

This type is, according Fleuriet, Kehdy and Blanc (1978), the most commonly found. This structure also has positive working capital, with financial assets exceeding onerous current liabilities, and cyclical current assets exceeding cyclical current liabilities.

Type III also observes a positive working capital, but the structure is considered as unsatisfactory because onerous current liabilities exceed financial current assets. 
This structure can be seen as transitory, as this unbalance can not be sustained in the long term. Therefore, it is expected that this structure be present in only a few companies. Type IV is described as the worst financial structure, in which cyclical current assets exceed cyclical current liabilities, but onerous current liabilities vastly exceed financial current assets, resulting in negative working capital.

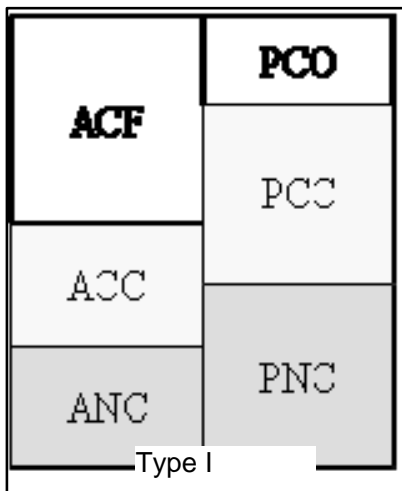

Tipo I

$C D G \geq 0$

NCG $<0$

$\mathbf{S T} \geq \mathbf{0}$

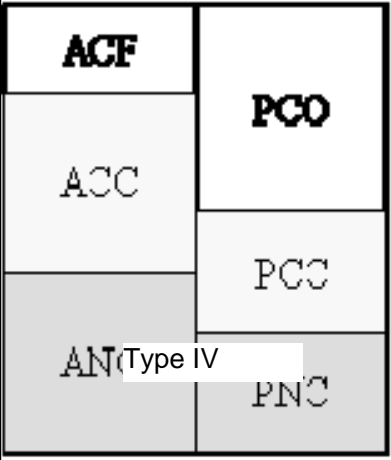

Tipo $\Gamma$

$C D G<0$

HCG $\geq 0$

$\mathrm{ST}<0$

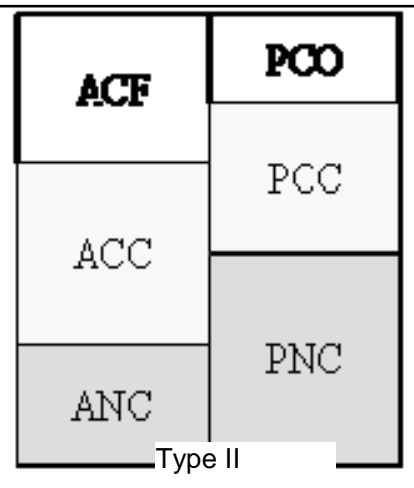

Tipo II

$C D G \geq 0$

$N C G \geq 0$

$3 T \geq 0$

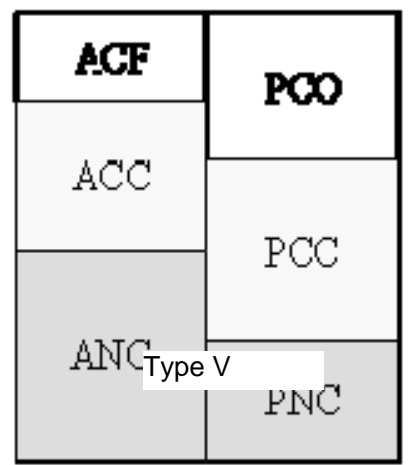

Tipo $V$

$C D G<0$

IKCG $<0$

$\mathrm{ST}<0$

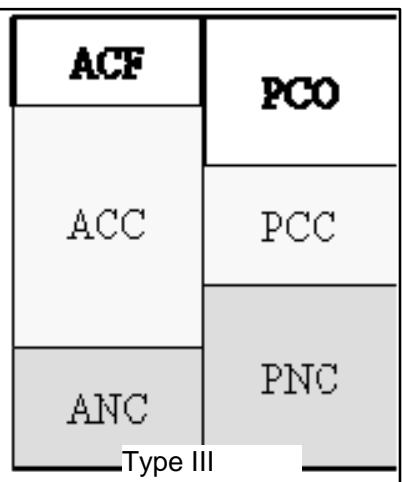

Tipo III

$C D G \geq 0$

$N C G \geq 0$

$\mathrm{ST}<\mathrm{C}$

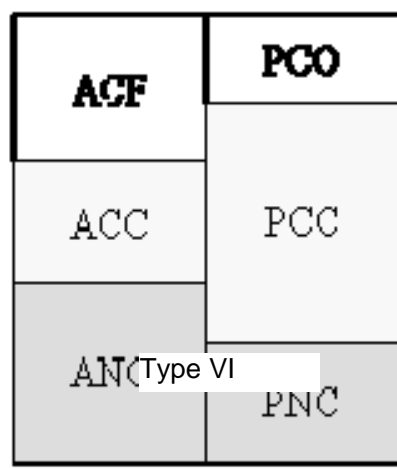

Tipo VI

CIG $<0$

NCG $<0$

$\mathrm{ST} \geq \mathrm{C}$

Image 2: Capital financing structure Fleuriet model Source: Prepared by the authors

Keys:

$$
\begin{array}{ll}
\text { ACC } & =\text { Cyclical Current Assets (or Operating) } \\
\text { ACF } & =\text { Financial Current Assets (or Erratic) } \\
\text { ANC } & =\text { Non-current Assets (or Long-term) } \\
\text { CDG } & =\text { Working capital } \\
\text { NCG } & =\text { Working capital Necessity } \\
\text { PCC } & =\text { Cyclical Current Liabilities (or Operating) } \\
\text { PCO } & =\text { Onerous Current Liabilities (or Erratic) } \\
\text { PNC } & =\text { Non-current Liabilities (or Long-term) } \\
\text { ST } & =\text { Cash Balance }
\end{array}
$$


Type $\mathrm{V}$ is described as a very bad, although better than type IV, in which onerous current liabilities exceed financial current assets and cyclical current liabilities exceed cyclical current assets, also resulting in negative working capital.Finally,Type VI is described as a structure of high risk, also showing negative working capital, with cyclical current liabilities exceeding cyclical current assets; however, financial current assets exceed onerous current liabilities.

The typology presented in the Fleuriet model facilitates visualizing how working capital is financed, hence its popularity does not come as a surprise. The typology also allows us to compare the six structures of working capital financing, and provides practical guidance on which structure is preferable.

Therefore, given the wide use of the model in Brazil (Brasil, 2003; Medeiros, 2005), the empirical validation of the typology presented in Fleuriet model is necessary and timely. However, as there is an important trade-off between the two goals of the working capital management: profitability and liquidity (Smith, 1980), and strategies for the working capital management may significantly impact both the liquidity as the profitability of the company (Shin e Soenen, 1998), the analyzed typology should not be assessed exclusively in terms of liquidity.

Finally, as profitability and liquidity are, in the long term, related to the solvency of the company, a more complete assessment of the typology should involve three dimensions: profitability, liquidity and solvency.

Therefore, this study evaluated whether different structures of working capital financing are associated with different levels of profitability, liquidity and solvency, displaying the theoretical pattern (Braga, 1991; Marques e Braga, 1995): structure type $\mathrm{I}=$ =xcellent; II=good, III=unsatisfactory, IV=very bad, V=bad, and VI=high risk. Or, formally, structure type I $>$ II $>$ III $>$ VI $>$ V $>$ IV.

Hypothesis 1. The profitability (profit) of the working capital financing structures follows the theoretical pattern: profit (I) > profit (II) > profit (III) > profit (VI) > profit (V) > profit (IV).

Hypothesis 2. The liquidity (net) of the working capital financing structures follows the theoretical pattern: net (I) > net (II) > net (III) > net (VI) > net (V) > net (IV). 
Hypothesis 3. The solvency (solv) of the working capital financing structures follows the theoretical pattern: $\operatorname{solv}$ (I) $>\operatorname{solv}$ (II) $>\operatorname{solv}($ III $)>\operatorname{solv~(VI)~}>\operatorname{solv}(\mathrm{V})>\operatorname{solv}($ IV).

In this article, we perform an empirical analysis of alternative working capital financing structures in terms of solvency, liquidity, and profitability. Through analysis of variance, we test whether the sample used supports the theorized preference order of working capital financing structures (Braga, 1991; Marques e Braga, 1995): from best to worst financial position - types I, II, III , IV, V and VI.

\section{METHODOLOGY}

This section describes the sample and environmental data collection, variables and procedures used in data analysis. The approach of this work is empirical-analytic, exploring collected data in order to test a theory.

\subsection{Sample and environment}

We collected economic and financial information (ANS, 2007) for the year 2006 from healthcare insurance companies operating in the Brazilian market. It is noteworthy that health plan regulation increases the uniformity and comparability of the sample, through shared features such as identical chart of accounts and minimum coverage.

From this database, we selected healthcare insurance companies, not taking into account companies offering exclusively dental care insurance. This restriction was imposed in order to increase the comparability of cases in the sample. Before statistical analysis, data were inspected, in order to identify inconsistent and extreme values.

The first step was to reject the observations with inconsistent values (i.e., with errors in data inputs or signals that prevent calculation, for example: negative revenue or total assets different from total liabilities). Finally, extreme values were removed for each type of financial structure (i.e., $\mathrm{Z}$ score values above and below the median somewhat 1.5 times the value of inter-quartile range). Table 3 describes the resulting sample, which comprised 621 Brazilian healthcare insurance companies.

\subsection{Variables}

This study uses four main constructs, namely: type of working capital financing structure, profitability, liquidity and solvency

\subsubsection{Type of working capital financing structure (type)}

Type indicates the working capital financing form, according to the detailed structures in Image 2. This variable is used as a factor in the analysis of variance and the operational BBR, Braz. Bus. Rev. (Engl. ed., Online), 
definition follows the advanced or dynamic analysis model of working capital management (Fleuriet, Kehdy e Blanc, 1978; Braga, 1991).

Table 3 - Description of statistic

\begin{tabular}{|c|c|c|c|c|c|c|c|c|c|}
\hline & \multirow{2}{*}{ Type } & \multirow{2}{*}{ No } & \multirow{2}{*}{ Mean } & \multirow{2}{*}{$\begin{array}{l}\text { Standard } \\
\text { Deviation }\end{array}$} & \multirow{2}{*}{$\begin{array}{l}\text { Standard } \\
\text { Error }\end{array}$} & \multicolumn{2}{|c|}{$\begin{array}{l}\text { Confidence Interval of } \\
\text { the Mean - 95\% }\end{array}$} & \multirow{2}{*}{ Min. } & \multirow{2}{*}{ Max. } \\
\hline & & & & & & Bottom Lim. & Top Lim. & & \\
\hline \multirow{6}{*}{ 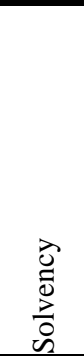 } & I & 260 & 3.3607 & 1.9648 & 0.1219 & 3.1208 & 3.6007 & -1.46 & 7.99 \\
\hline & II & 204 & 4.6016 & 2.3899 & 0.1673 & 4.2716 & 4.9315 & -0.17 & 10.71 \\
\hline & III & 30 & 1.4297 & 1.5394 & 0.2811 & 0.8549 & 2.0045 & -1.36 & 5.19 \\
\hline & IV & 7 & 0.3006 & 0.9763 & 0.3690 & -0.6023 & 1.2035 & -0.82 & 1.69 \\
\hline & $\mathrm{V}$ & 56 & -1.6472 & 1.9150 & 0.2559 & -2.1600 & -1.1343 & -6.79 & 1.96 \\
\hline & VI & 64 & -1.9742 & 3.1502 & 0.3938 & -2.7611 & -1.1873 & -11.70 & 2.40 \\
\hline \multirow{6}{*}{ 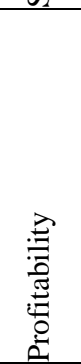 } & I & 260 & 0.0394 & 0.0420 & 0.0026 & 0.0343 & 0.0446 & -0.07 & 0.15 \\
\hline & II & 204 & 0.0653 & 0.0730 & 0.0051 & 0.0552 & 0.0754 & -0.05 & 0.30 \\
\hline & III & 30 & 0.0159 & 0.0405 & 0.0074 & 0.0008 & 0.0311 & -0.04 & 0.14 \\
\hline & IV & 7 & 0.0056 & 0.0500 & 0.0189 & -0.0406 & 0.0519 & -0.09 & 0.06 \\
\hline & V & 56 & -0.0668 & 0.1072 & 0.0143 & -0.0955 & -0.0381 & -0.36 & 0.05 \\
\hline & VI & 64 & -0.0268 & 0.0530 & 0.0066 & -0.0400 & -0.0136 & -0.21 & 0.02 \\
\hline \multirow{6}{*}{ 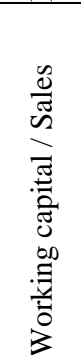 } & I & 260 & 0.1322 & 0.1317 & 0.0082 & 0.1161 & 0.1483 & 0.00 & 0.88 \\
\hline & II & 204 & 0.2832 & 0.4023 & 0.0282 & 0.2277 & 0.3387 & 0.02 & 2.93 \\
\hline & III & 30 & 0.2087 & 0.8621 & 0.1574 & -0.1132 & 0.5306 & 0.00 & 4.77 \\
\hline & IV & 7 & -0.0215 & 0.0203 & 0.0077 & -0.0403 & -0.0028 & -0.05 & 0.00 \\
\hline & V & 56 & -0.2864 & 0.3155 & 0.0422 & -0.3709 & -0.2019 & -1.22 & -0.01 \\
\hline & VI & 64 & -0.1845 & 0.4723 & 0.0590 & -0.3025 & -0.0665 & -3.03 & 0.00 \\
\hline \multirow{6}{*}{ 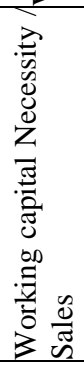 } & I & 260 & -0.0636 & 0.1232 & 0.0076 & -0.0787 & -0.0486 & -1.82 & 0.00 \\
\hline & II & 204 & 0.0979 & 0.2275 & 0.0159 & 0.0665 & 0.1293 & 0.00 & 2.38 \\
\hline & III & 30 & 0.6608 & 3.0515 & 0.5571 & -0.4786 & 1.8002 & 0.01 & 16.81 \\
\hline & IV & 7 & 0.0256 & 0.0165 & 0.0062 & 0.0104 & 0.0408 & 0.01 & 0.05 \\
\hline & $\mathrm{V}$ & 56 & -0.1853 & 0.2377 & 0.0318 & -0.2489 & -0.1216 & -1.10 & 0.00 \\
\hline & VI & 64 & -0.2431 & 0.5111 & 0.0639 & -0.3708 & -0.1155 & -3.07 & -0.01 \\
\hline \multirow{6}{*}{ 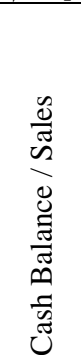 } & I & 260 & 0.1959 & 0.2059 & 0.0128 & 0.1707 & 0.2210 & 0.01 & 2.42 \\
\hline & II & 204 & 0.1853 & 0.3127 & 0.0219 & 0.1421 & 0.2285 & 0.00 & 2.63 \\
\hline & III & 30 & -0.4521 & 2.1907 & 0.4000 & -1.2701 & 0.3659 & -12.04 & 0.00 \\
\hline & IV & 7 & -0.0471 & 0.0334 & 0.0126 & -0.0780 & -0.0162 & -0.10 & -0.01 \\
\hline & $\mathrm{V}$ & 56 & -0.1012 & 0.1650 & 0.0221 & -0.1453 & -0.0570 & -0.84 & 0.00 \\
\hline & VI & 64 & 0.0586 & 0.1459 & 0.0182 & 0.0222 & 0.0951 & 0.00 & 1.05 \\
\hline
\end{tabular}

Source: Prepared by the authors. 


\subsubsection{Profitability}

Profitability measures the company's ability to generate profit. A very common company's profitability measure is used in this study: the operating profit margin, obtained by dividing operating profit by total net sales. A feature of the operating margin is that it allows comparisons between companies of different sizes, possibly more accurately than other financial ratios such as return on assets and return on equity, mainly because the denominator revenues (i.e., in this case, insurance premium) is a far more representative and less biased indicator of the size of operation than total assets or total equity, especially in extreme cases of financial distress.

\subsubsection{Liquidity}

Liquidity indicates the company's ability to meet its financial obligations in a timely manner, without affecting normal operation. It's a measure related to working capital and its financing. Algebraically, the relationship between working capital and liquidity (i.e., current ratio, which is the most commonly used liquidity ratio) can be checked through the formulas:

- Current Ratio = Current Assets $/$ Current Liabilities

- Working capital $=$ Current Assets - Current Liabilities

Liquidity and solvency are essential for healthcare insurance companies (D’Oliveira, 2006). Lack of liquidity means delays in honoring obligations with service providers. If this situation is sustained over a long period, the market is likely to be negatively impacted, eventually leading to - in the worst case - patients failing to receive needed care. Shulman and Cox (1985) noted that cash balance (ST) is a more accurate indicator of the actual liquidity of the company than well known liquidity ratios as current or quick ratio.

For this reason, we chose to measure liquidity in terms of working capital (CDG) and its components: cash balance (ST) and working capital necessity (NCG) - the three components of the working capital identity in the Fleuriet model. To allow the comparison of companies of different sizes, variables (i.e., CDG, NCG and ST) were divided by total net sales. Together, these variables also determine the type of working capital financing structure.

\subsubsection{Solvency}

Solvency indicates the company's ability to repay their debts in a liquidation scenario. Unlike liquidity, solvency is related to both long and short term assets and liabilities. Briefly stated, measures of solvency assess what would happen if all assets were sold and converted into cash for payment of obligations. It is not useful just to calculate whether a company is 
solvent or insolvent. Instead, what we want is the ability to anticipate or predict the prospect of future insolvency, before the worsening financial difficulties and the company becomes insolvent.

This is exactly the purpose of insolvency prediction models, which can be based on different methodologies such as discriminant analysis, logistic regression, probit, neural networks etc. (Altman e Hotchkiss, 2006). A common feature of these methodologies is the rigorous treatment of variables in order to classify te status, or estimate the probability of future insolvency of the company. A widespread insolvency prediction model (Grice e Ingramb, 2001) is Altman's Z score (Altman, 1968; Altman, Haldeman e Narayanan, 1977; Altman, Baidya e Dias, 1979; Altman e Hotchkiss, 2006).

The pioneering model, originated more than forty years ago, applied discriminant analysis in order to predict future insolvency on the basis of accounting and financial data. In this study, we adopted the generic model for private companies, known as Z”. The Z” model is calculated from the formula: $Z$ ” $=6,56 X_{1}+3,26 X_{2}+6,72 X_{3}+1,05 X_{4}$, where: $X_{1}=$ working capital / total assets; $\mathrm{X}_{2}$ = retained earnings / total assets; $\mathrm{X}_{3}=$ earnings before taxes and fees / total assets, and $\mathrm{X}_{4}=$ equity / total assets.

In the model, the values under 1,1 indicate a high risk of insolvency, and values higher than 2,6 indicate a low risk of insolvency, while values between 1,1 and 2,6 represent a gray area (i.e., uncertainty). No transformation is necessary to use the Z” score as a solvency measure because higher values of Z” scores indicate greater solvency and low values indicate insolvency. Table 4 shows that a number of distressed healthcare insurers (n.b.: it was used a convenience sample, for illustration only) could have been predicted by Altman's model Z”.

Table 4 - Examples of Altman z" application on healthcare insurance companies

\begin{tabular}{c|c|c|c}
\hline Company & Reviewed Financial Statements & Z'” & Settlement Date \\
\hline A & June/2002 & -3.01 & $12 / 23 / 2004$ \\
\hline B & December/2004 & 1.08 & $04 / 20 / 2006$ \\
\hline C & December /2002 & -32.03 & $04 / 01 / 2005$ \\
\hline D & December /2001 & -22.57 & $05 / 25 / 2006$ \\
\hline E & December /2002 & 0.53 & $10 / 19 / 2004$ \\
\hline F & December /2001 & -4.87 & $08 / 22 / 2005$ \\
\hline
\end{tabular}

Source: Prepared by the authors, from ANS data.

\subsection{Data Review}

A simple analysis of variance of liquidity, solvency and profitability for different working capital financing structures was performed (i.e., a factor with six levels, referring to the types of structures theorized by Braga, 1991), to better understand the differences between the types of structure. ANOVA assumptions were observed, confirming the independence of 
observations and the absence of significant violations of normality (i.e., KolmogorovSmirnov). The sample violates, however, the assumption of homogeneity of variance, as indicated by the Levene test: $F(5,613)=16,947, p<0,001$. Considering the size of the sample $(\mathrm{n}=621)$ and following the recommendation of Gliner and Morgan (2000, p. 229), we sought to confirm the results obtained from analysis of variance, using a nonparametric equivalent method for more than two groups: the H test of Kruskal-Wallis. The results are presented and discussed in the following sections.

\section{RESULTS}

A simple analysis of variance (i.e., between-groups, univariate analysis) was conducted to explore the working capital financing structure impact on solvency (i.e., Z” score), profitability (i.e., operating profit margin) and liquidity (i.e., working capital / sales, working capital necessity / sales, cash balance / sales) of healthcare insurance companies.

The variables inspected showed statistically significant differences at $\mathrm{p}<0,001$ for the six types of working capital financing structure. ANOVA results are listed in Table 5. The variable regarding the insolvency showed a particularly strong impact (Cohen, 1988), as indicate by the high eta-squared (i.e., $\eta 2=0.53$ ). The profitability represented by operating profit margin (i.e., $\eta 2=0.30$ ) and the liquidity measured by working capital over net sales (i.e., $\eta 2=0.21)$ also indicated strong effects (Cohen, 1988).

Table 5 - ANOVA results

\begin{tabular}{|c|c|c|c|c|}
\hline & & Sum of Squares & Degrees of Freedom & $\mathbf{F}$ \\
\hline \multirow{3}{*}{$\begin{array}{l}\text { Insolvency } \\
\eta^{2}=0.53\end{array}$} & Between Groups & 3394.132 & 5 & $136.401^{*}$ \\
\hline & Inside Groups & 3060.660 & 615 & \\
\hline & Total & 6454.793 & 620 & \\
\hline \multirow{3}{*}{$\begin{array}{l}\text { Profitability } \\
\eta^{2}=0.30\end{array}$} & Between Groups & 1.019 & 5 & $51.969 *$ \\
\hline & Inside Groups & 2.411 & 615 & \\
\hline & Total & 3.430 & 620 & \\
\hline \multirow{3}{*}{$\begin{array}{l}\text { CDG / Earnings } \\
\eta^{2}=0.21\end{array}$} & Between Groups & 21.006 & 5 & $32.945^{*}$ \\
\hline & Inside Groups & 78.425 & 615 & \\
\hline & Total & 99.431 & 620 & \\
\hline \multirow{3}{*}{$\begin{array}{l}\text { NCG / Sales } \\
\eta^{2}=0.07\end{array}$} & Between Groups & 21.808 & 5 & $8.822 *$ \\
\hline & Inside Groups & 304.042 & 615 & \\
\hline & Total & 325.850 & 620 & \\
\hline \multirow{3}{*}{$\begin{array}{l}\text { ST / Sales } \\
\eta^{2}=0.08\end{array}$} & Between Groups & 15.356 & 5 & 10.927* \\
\hline & Inside Groups & 172.857 & 615 & \\
\hline & Total & 188.214 & 620 & \\
\hline
\end{tabular}

* significant, $\mathrm{p}<0.001$

Source: Prepared by the authors. 
Table 6 - ANOVA POST-HOC Contrasts

\begin{tabular}{|c|c|c|c|c|c|c|c|}
\hline & & 1 & 2 & 3 & 4 & 5 & 6 \\
\hline 1 & $\begin{array}{l}\text { Solvency (Z”) } \\
\text { Profitability (Operating Margin) } \\
\text { Liquidity (CDG / Net Sales) }\end{array}$ & $\begin{array}{l}- \\
- \\
-\end{array}$ & $\begin{array}{l}-1.24^{*} \\
-0.03^{*} \\
-0.15^{*}\end{array}$ & $\begin{array}{l}1.93 * \\
0.02 * \\
-0.08\end{array}$ & $\begin{array}{l}3.06^{*} \\
0.03 \\
0.15^{*}\end{array}$ & $\begin{array}{l}5.01^{*} \\
0.11^{*} \\
0.42 *\end{array}$ & $\begin{array}{l}5.33^{*} \\
0.07 * \\
0.32 *\end{array}$ \\
\hline 2 & $\begin{array}{l}\text { Solvency (Z”) } \\
\text { Profitability (Operating Margin) } \\
\text { Liquidity (CDG / Net Sales) } \\
\end{array}$ & $\begin{array}{l}1.24^{*} \\
0.03^{*} \\
0.15^{*}\end{array}$ & $\begin{array}{l}- \\
- \\
- \\
\end{array}$ & $\begin{array}{l}3.17 * \\
0.05^{*} \\
0.07\end{array}$ & $\begin{array}{l}4.30^{*} \\
0.06 \\
0.30^{*}\end{array}$ & $\begin{array}{l}6.25 * \\
0.13^{*} \\
0.57 *\end{array}$ & $\begin{array}{l}6.58 * \\
0.09 * \\
0.47 *\end{array}$ \\
\hline 3 & $\begin{array}{l}\text { Solvency (Z”) } \\
\text { Profitability (Operating Margin) } \\
\text { Liquidity (CDG / Net Sales) }\end{array}$ & $\begin{array}{l}-1.93^{*} \\
-0.02 * \\
0.08\end{array}$ & $\begin{array}{l}-3.17^{*} \\
-0.05^{*} \\
-0.07\end{array}$ & $\begin{array}{l}- \\
- \\
-\end{array}$ & $\begin{array}{l}112.91 \\
0.01 \\
0.23\end{array}$ & $\begin{array}{l}3.08 * \\
0.08 * \\
0.50 *\end{array}$ & $\begin{array}{l}3.40^{*} \\
0.04^{*} \\
0.39\end{array}$ \\
\hline 4 & $\begin{array}{l}\text { Solvency (Z”) } \\
\text { Profitability (Operating Margin) } \\
\text { Liquidity (CDG / Net Sales) }\end{array}$ & $\begin{array}{l}-3.06 * \\
-0.03 \\
-0.15^{*}\end{array}$ & $\begin{array}{l}-4.30 * \\
-0.06 \\
-0.30 *\end{array}$ & $\begin{array}{l}-112.91 \\
-0.01 \\
-0.23\end{array}$ & $\begin{array}{l}- \\
- \\
-\end{array}$ & $\begin{array}{l}1.95^{*} \\
0.07 * \\
0.26 *\end{array}$ & $\begin{array}{l}2.27^{*} \\
0.03 \\
0.16^{*}\end{array}$ \\
\hline 5 & $\begin{array}{l}\text { Solvency (Z”) } \\
\text { Profitability (Operating Margin) } \\
\text { Liquidity (CDG / Net Sales) } \\
\end{array}$ & $\begin{array}{l}-5.01^{*} \\
-0.11^{*} \\
-0.42^{*}\end{array}$ & $\begin{array}{l}-6.25^{*} \\
-0.13^{*} \\
-0.57^{*}\end{array}$ & $\begin{array}{l}-3.08 * \\
-0.08 * \\
-0.50 * \\
\end{array}$ & $\begin{array}{l}-1.95^{*} \\
-0.07^{*} \\
-0.26^{*}\end{array}$ & $\begin{array}{l}- \\
- \\
- \\
-\end{array}$ & $\begin{array}{l}0.33 \\
-0.04 \\
-0.10 \\
\end{array}$ \\
\hline 6 & $\begin{array}{l}\text { Solvency (Z”) } \\
\text { Profitability (Operating Margin) } \\
\text { Liquidity (CDG / Net Sales) }\end{array}$ & $\begin{array}{l}-5.33^{*} \\
-0.07 * \\
-0.32 *\end{array}$ & $\begin{array}{l}-6.58^{*} \\
-0.09^{*} \\
-0.47^{*}\end{array}$ & $\begin{array}{l}-3.40^{*} \\
-0.04^{*} \\
-0.39\end{array}$ & $\begin{array}{l}-2.27^{*} \\
-0.03 \\
-0.16^{*}\end{array}$ & $\begin{array}{l}-0.33 \\
0.04 \\
0.10\end{array}$ & $\begin{array}{l}- \\
- \\
-\end{array}$ \\
\hline
\end{tabular}

* significant at level $\mathrm{p}<0.10$

Source: Prepared by the authors

Separately, the two working capital components, working capital necessity / net sales (i.e. $\eta 2=0.07$ ) and the cash balance / net sales (i.e., $\eta 2=0.08$ ), observed average intensity effects (Cohen, 1988). In order to validate the difference between groups, Games-Howell polynomial contrasts were performed, comparing each group with the others (see Table 6).

Table 7 -Results of KRUSKAL-WALLIS' H Test

\begin{tabular}{|c|c|c|c|c|c|}
\hline & $\begin{array}{l}\text { Insolvency (Z" } \\
\text { score) }\end{array}$ & $\begin{array}{l}\text { Profitability } \\
\text { (Operating } \quad \text { Profit } \\
\text { Margin) }\end{array}$ & $\begin{array}{l}\text { CDG / Net } \\
\text { Sales }\end{array}$ & $\begin{array}{l}\text { NCG / Net } \\
\text { Sales }\end{array}$ & $\begin{array}{l}\text { ST / Net } \\
\text { Sales }\end{array}$ \\
\hline Chi-square & $322.572 *$ & $181.068^{*}$ & $347.500^{*}$ & 465.869* & 311.306* \\
\hline
\end{tabular}

* significant, $\mathrm{p}<0.001$, with 5 degrees of freedom.

Source: Prepared by the authors

Tests showed significant differences for most contrasts (i.e., $\mathrm{p}<0.10$ ) except between types III and IV and between types V and VI. As the sample violated the assumption of homogeneity of variance (Gliner and Morgan, 2000, p. 229), we followed the ANOVA with Kruskal-Wallis' H Test (also known as the Kruskal-Wallis One-Way Analysis of Variance by Ranks), which is the nonparametric equivalent of analysis of variance for three or more groups.

Test results indicated that distributions of variables differ significantly (i.e., at level $\mathrm{p}$ $<0.001$ ) across the six types of working capital financing structure, corroborating the parametric ANOVA results.Pictures 3 to 5 show the confidence intervals of the means of 
solvency, liquidity and profitability measures across the six types of working capital financing structures.

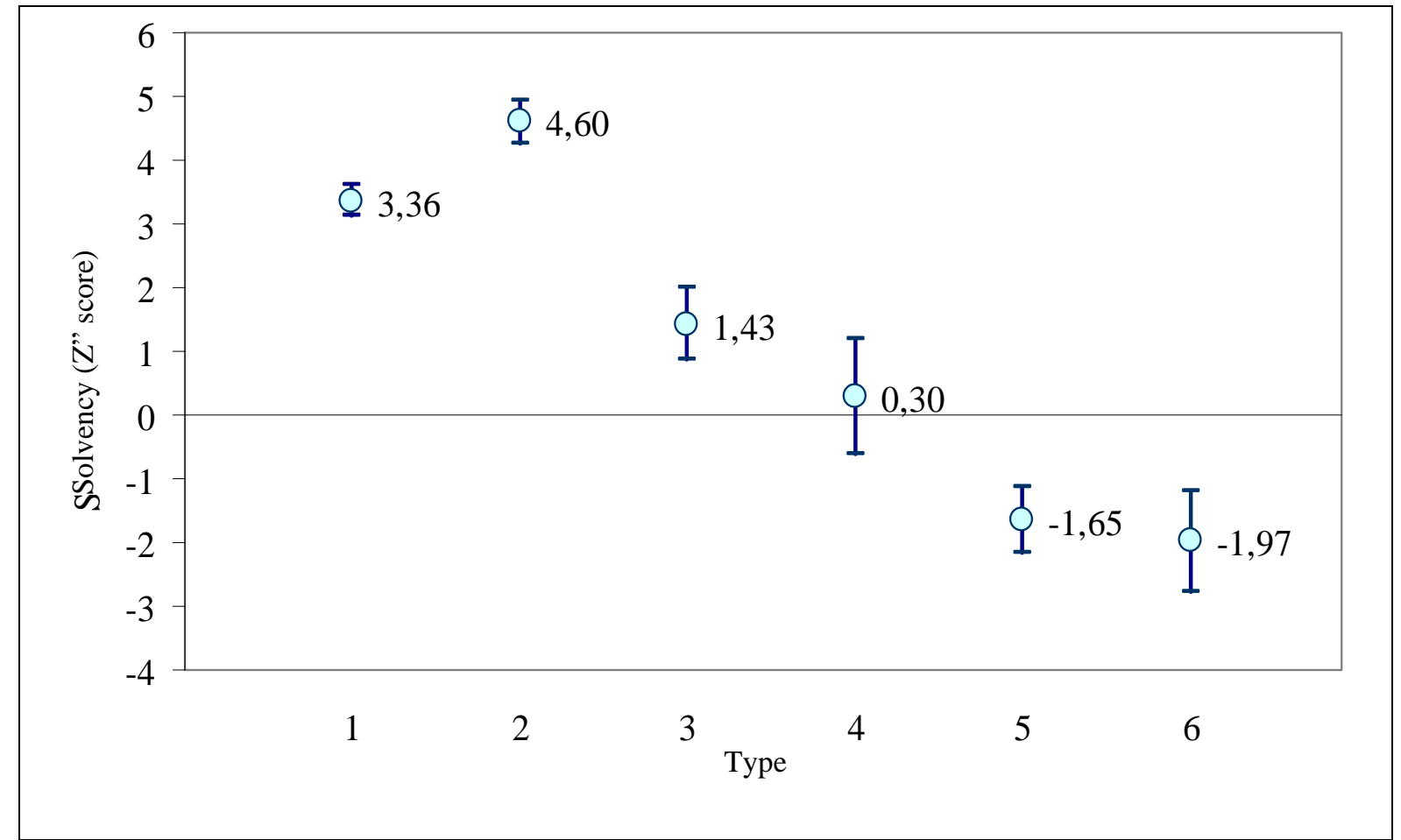

Image 3 - Mean solvency (95\% confidence interval) of working capital financing structures Source: Prepared by the authors

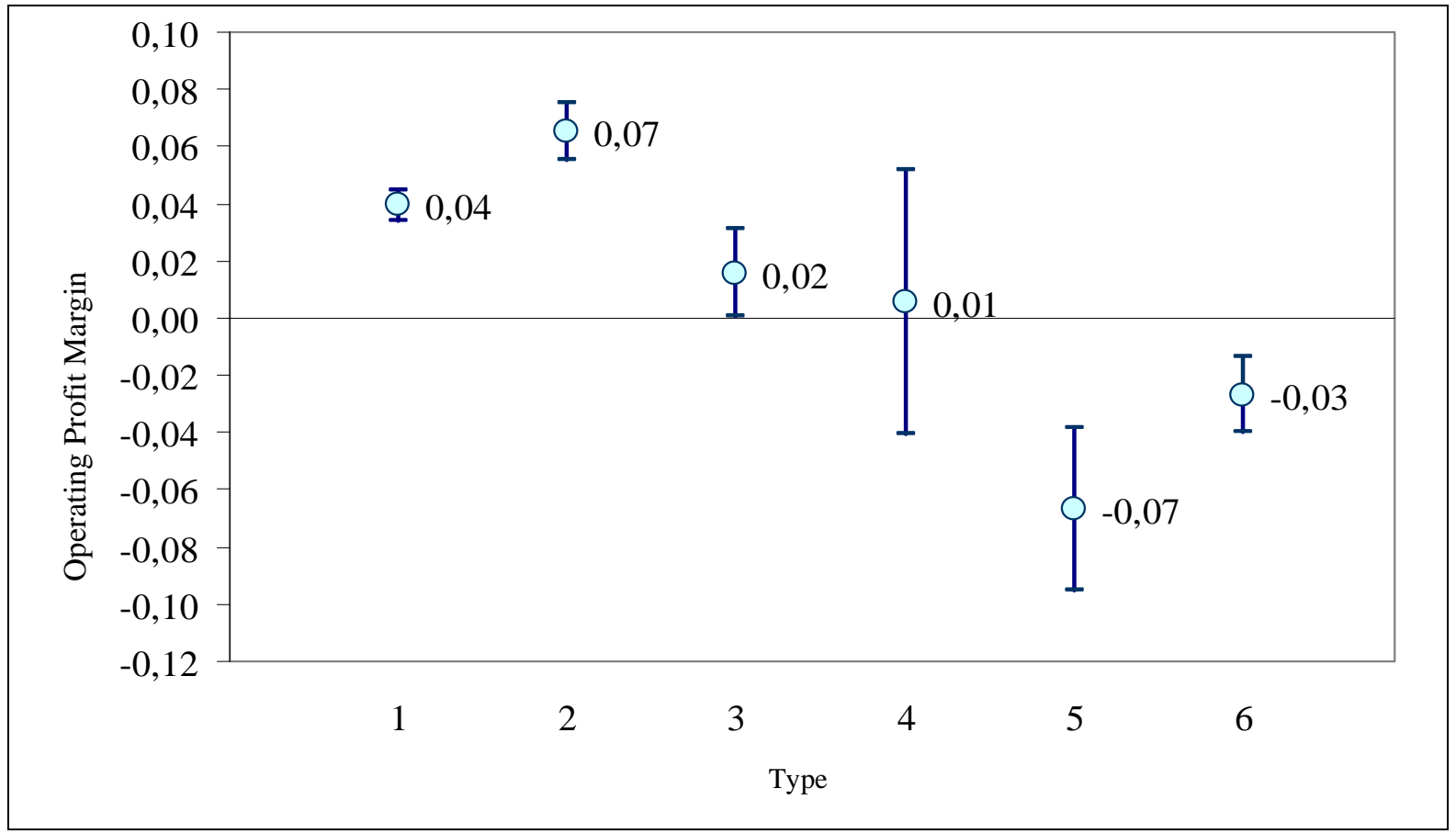

Image 4 - Mean profitability (95\% confidence interval) of working capital financing structures. Source: Prepared by the authors 


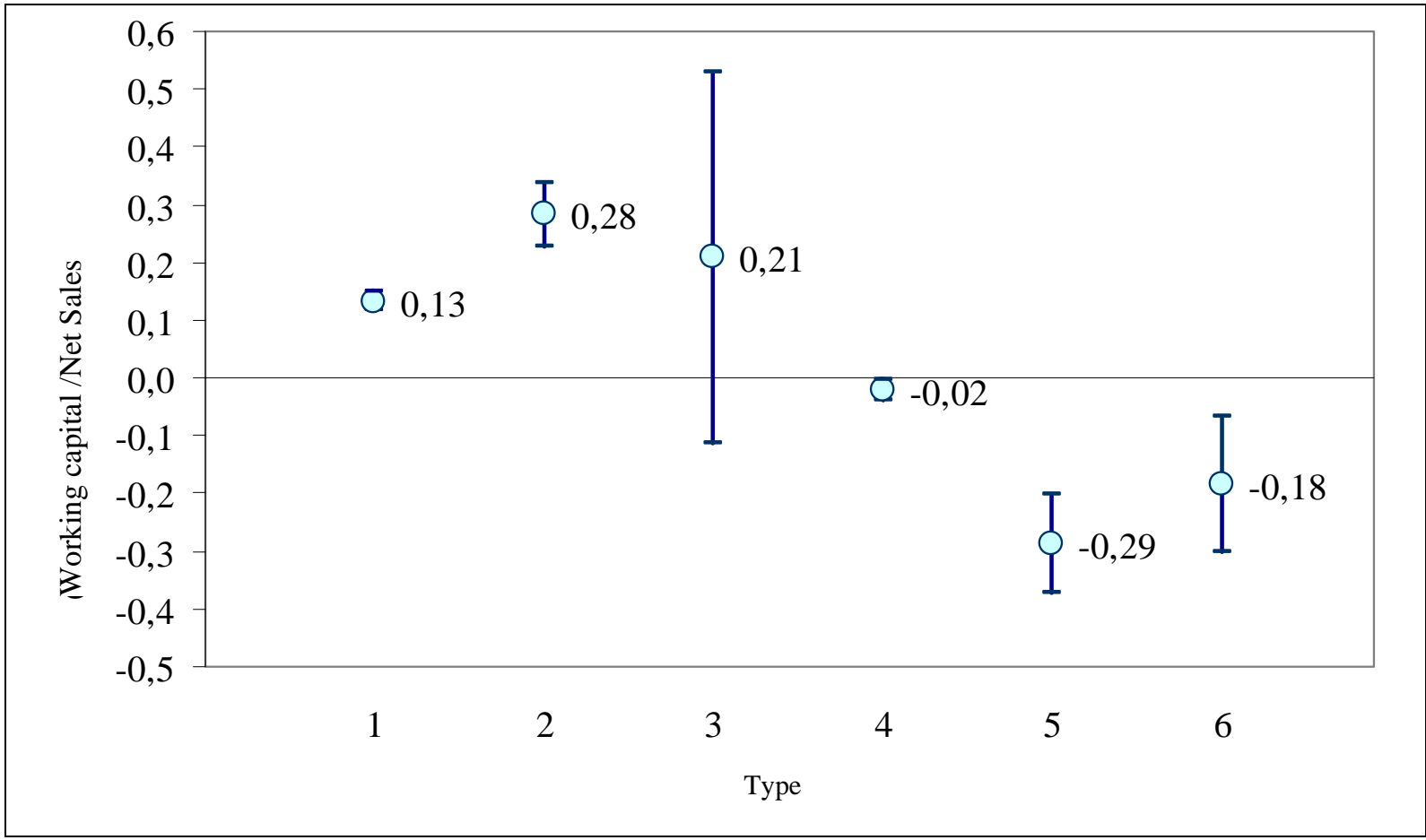

Image 5 - Mean working capital / net sales (95\% conf. interval) of working capital financing structures. Source: Prepared by the authors

In terms of solvency (Image 3), contrary to the theorized (Braga, 1991; Marques e Braga, 1995), the type II presents a higher solvency than the type I. Moreover, the structure of type IV is higher than type V, without significant difference between the structures of the type $\mathrm{V}$ and VI. Considering the profitability (Image 4), the working capital financing structure of type II is also higher than type I. And once again, the structure of type V is lower than a structure of type IV.

In terms of liquidity (Image 5), measured by working capital over total net sales, we observe the same pattern: type II scores higher than type I, and type V scores lower than type IV, although not significantly different from type VI.

Briefly, the sample analyzed does not support the hypothesis that the working capital financing structure - when evaluated in terms of profitability, solvency and liquidity - exhibit the theorized preference order (Fleuriet, Kehdy e Blanc, 1978; Braga, 1991; Marques e Braga, 1995; Fleuriet, Kehdy e Blanc, 2003), that a structure of type I is the best, followed by a type II as the second best, III is unsatisfactory, type IV is the worst structure, type V is a bad structure, and structure VI is a high risk. Instead, empirical analysis shows that among the six types of working capital financing structure, type II is superior to type I in terms of liquidity, profitability and solvency. Moreover, our results indicate that among the six types of working capital financing structure, the type $\mathrm{V}$ is the worst; that is, lower than the type IV. 


\subsection{Discussion}

Our empirical results show inconsistencies in the analysis of the financial situation of the different working capital financing structures. Contrary to current theory (Braga, 1991; Marques e Braga, 1995), our analysis shows that type II structures present better profitability, liquidity and solvency scores than type I structures.

This is explained by the better match between assets and liabilities in the short term, both in financial and operational perspective. In terms of liquidity, the difference is small and non-significant. The mean cash balance of a type I firm is $19.59 \%$ of annual net sales, while for a type II firm it is $18.47 \%$.

Similar inconsistencies exist in types IV, V and VI. Results indicate that type IV may not be the least desirable. Instead, this study suggests that type IV is possibly a transitional structure. The low number of cases showing this structure, as well as the behavior of profitability and solvency compared to types V and VI, support this argument. Although the type IV firm shows positive working capital necessity (i.e., NCG>0), short-term financial liabilities far exceed financial assets.

As onerous current liabilities cost more (i.e., than operating liabilities, in most cases), the type IV firm will probably seek to replace bank financing with operations (i.e., based on vendors/providers), becoming a type VI. This seems, in general, a rational practice since this source of funding tends to be cheaper. However, in some cases this is not a valid option for various reasons (e.g., lack of credit, low bargaining power of the company, market characteristics, etc.).

If the deficit is too large, this financial strategy might not be able to solve the company's problem permanently, although it may be useful in the short term. As the type IV structure tends to be transient, the company can restructure its debt and operations by taking more attractive forms (types I, II or III) or further deteriorate the situation to a type V.

The mean cash balance for a type IV firm represents $-4.71 \%$ of net sales a year, which is not really as bad as that of a type V firm: $-10.12 \%$. So, type V scores, according to our results, lower than type IV. In fact, the analysis indicates that type V is the worst of the six structures, because its negative working capital comes from both financial and operational deficits (i.e., $\mathrm{ST}<0$, NCG $<0$ )Although there is no statistically significant difference between types V and VI, operationally, a type VI firm is not really as bad as a Type V firm, because it fares better financially. 
This situation is also not sustainable in the long term, not only because equity is being eroded, but also because investors might seek better investment alternatives. If the operating imbalance does not occur due to new investments that might generate better results in the future, the company's survival may be at risk.

Despite these inconsistencies, our analysis suggests that the Fleuriet model can provide managers with a useful visualization of working capital financing structure of their businesses. However, inferences about what structures are to be preferred deserve greater scrutiny.

The analysis performed confirms that different working capital financing structures are associated with different levels of profitability, liquidity and solvency of healthcare insurance companies. However, empirical research does not corroborate the theorized order of preference (Braga, 1991; Marques e Braga, 1995).

Instead, an alternative order of preference is proposed, along with a list of relevant management considerations associated with each type of structure (see Table 8). In summary, our results show that type II firms - in which financial assets exceed financial liabilities, and operating assets exceed operating liabilities - are associated with higher levels of profitability, solvency and liquidity.

When investigating the source of discrepancies between our empirical results and the theoretical argument (Braga, 1991; Marques e Braga, 1995), it seems conceivable that the discrepancy arises from the fact that types I and II do not discriminate sufficiently the underlying funding structures.

Further analysis showed that types can be subdivided. The different sub-types create a more detailed typology comprising ten structures, as shown in Image 6. For example, type II, which in the sample showed superior performance can be divided into two subtypes: subtype II-A satisfies the type II criteria, but is essentially closer to Fleuriet's type I, while subtype II$\mathrm{B}$ is closer to Type II as originally theorized.

The same effect occurs, for example, with types I, IV and V. Types I-A and I-B showed up with similar frequency. The same happened with the two varieties of type II. Among types IV and V, however, the occurrence of subtypes IV-B (i.e., 1 / 11) and VB (i.e., 6 / 73) was infrequent, indicating that these structures might be transitory or even represent a terminal situation. 
Table 8 - Working capital financing structures revisited

\begin{tabular}{|c|c|c|c|c|c|c|}
\hline $\begin{array}{c}\text { Typ } \\
\text { e }\end{array}$ & $\begin{array}{c}\text { Working } \\
\text { capital (CDG) }\end{array}$ & $\begin{array}{l}\text { Working capital } \\
\text { Necessity (NCG) }\end{array}$ & $\begin{array}{c}\text { Cash } \\
\text { Balance } \\
\text { (NLB) }\end{array}$ & & lancial Status & $\begin{array}{c}\text { Managerial } \\
\text { Considerations }\end{array}$ \\
\hline I & + & - & + & ;:) & Good & $\begin{array}{l}\text { Excessive } \\
\text { Liquidity? }\end{array}$ \\
\hline II & + & + & + & $\begin{array}{l}+; \\
: ; \\
;\end{array}$ & Very Good & $\begin{array}{c}\text { Excellent! Can it } \\
\text { be improved? }\end{array}$ \\
\hline III & + & + & - & $\odot$ & Risky & $\begin{array}{c}\text { Reduce financial } \\
\text { liabilities. }\end{array}$ \\
\hline IV & - & + & - & : & Bad and Risky & $\begin{array}{c}\text { Reduce financial } \\
\text { liabilities. } \\
\text { Improve } \\
\text { profitability. }\end{array}$ \\
\hline V & - & - & - & $\begin{array}{l}: 0 \\
: 0 \\
: 0\end{array}$ & Very Bad & \multirow{2}{*}{$\begin{array}{l}\text { Is the instability } \\
\text { temporary? } \\
\text { Is it possible to } \\
\text { improve the } \\
\text { profitability and } \\
\text { attract new } \\
\text { investors? }\end{array}$} \\
\hline VI & - & - & + & $\begin{array}{l}: 0 \\
: 0\end{array}$ & Bad & \\
\hline
\end{tabular}

$+\quad$ indicate positive values (higher or equal zero)

- $\quad$ indicate negative values

Source: Prepared by the authors

Regardless of the order of preference (i.e., as recommended by Braga and co-authors, or suggested in this article), the study indicates that relying on healthcare insurance companies with working capital financing structures types IV, V and VI requires special attention, because it is possible that the contract and the effective provision of services might be at risk if the adverse financial situation of the company is not reversed.

The results also suggest that the Fleuriet model can also be helpful in the economic regulation of the sector, allowing regulators to concentrate their attention in companies with poor working capital financing structures (i.e., types IV, V and VI, i.e. CDG<0). 


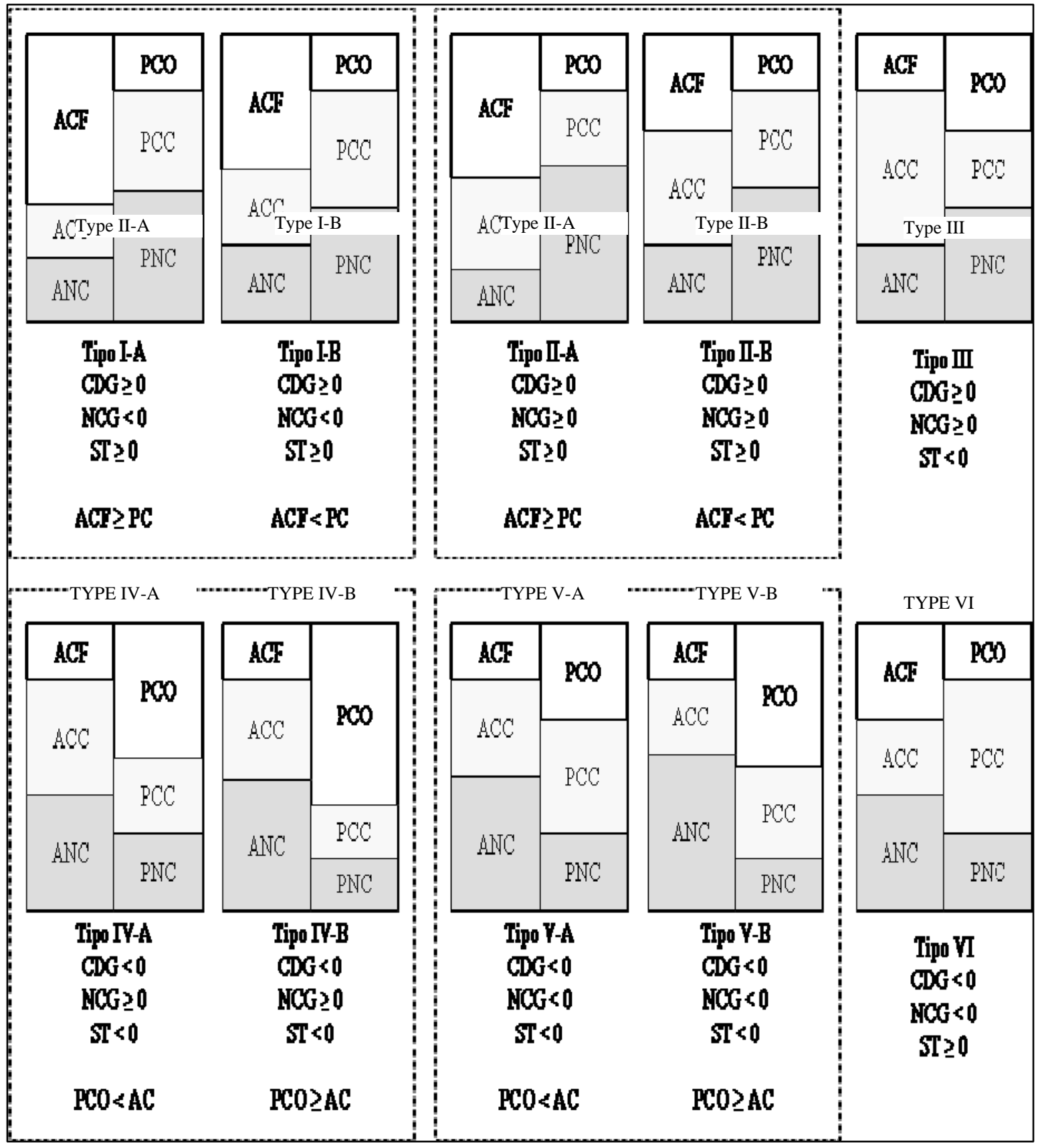

Image 6 - Sub-types of Fleuriet model

Source: Prepared by the authors

Keys:

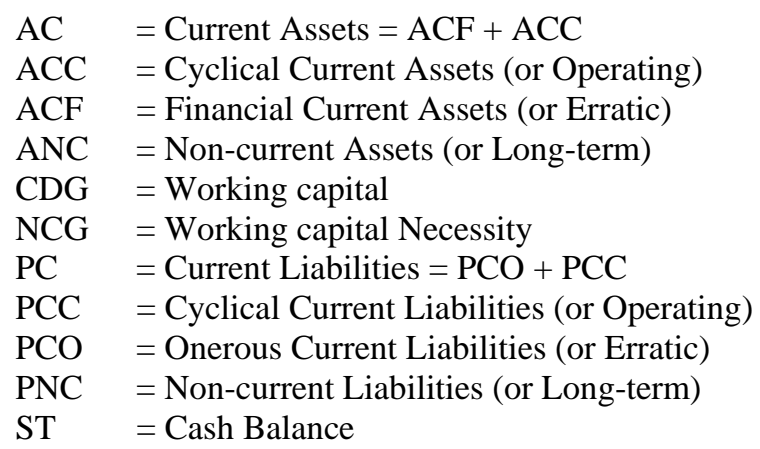




\section{CONCLUSION}

Among the most important strategic decisions of managers are those involving the financing of the company (Barton e Gordon, 1987). Nevertheless, organizational research has produced few works in this area (Mizruchi e Stearns, 1994). This study supports the notion that effective management of working capital is important for the financial health of healthcare insurers.

The integration of strategic planning to the capital budget process, with special attention to alternative working capital financing structures, may be useful for companies of all sizes and should not be restricted to large corporations, deserving greater attention from organizational researchers and practitioners.

It is significant that this study is limited to healthcare insurance companies. It is hoped that future work may extend or replicate this work in a sample covering multiple sectors of the economy in order to verify whether our findings are generalizable, and evaluate the usefulness of the subtypes identified in this study, elaborating its theoretical and practical implications.

The results presented in this article are empirical evidence with academic and practical implications. Academically, the results help to clarify some concepts that may have been taken in error, in the current literature on the attractiveness of each working capital financing structure (Braga, 1991; Marques e Braga, 1995), when viewed from the perspective of profitability, liquidity and solvency. Also, this study suggests that components of the dynamic model of Fleuriet may be important variables in the development and refinement of insolvency prediction models.

For regulators and policymakers, this study indicates that the models presented (i.e., Fleuriet for working capital management and Altman's Z” score for insolvency prediction) can be useful tools for economic and financial regulation.

One potential application would be the focus of regulatory presence in companies with weaker working capital structures or at high risk of insolvency, something highly desirable when we consider that regulatory agencies often have a limited number of qualified specialists to perform the economic-financial analysis for a large number of regulated companies.

Finally, for managers, the results reaffirm the importance of efficient working capital management, and show that the model developed by Fleuriet, Kehdy and Blanc can be a useful tool in visualizing, understanding and planning of the capital needs of their companies. 


\section{REFERENCES}

ALTMAN, E. I. Financial ratios, discriminant analysis and the prediction of corporate bankruptcy. Journal of Finance, v. 23, n. 4, p. 589, 1968.

ALTMAN, E. I; BAIDYA, T. K. N.; DIAS, L. M. R. Assessing potential financial problems for firms in Brazil. Journal of International Business Studies, v. 10, n. 2, p. 9, 1979.

ALTMAN, E. I; HALDEMAN, R. G.; NARAYANAN, P. Zeta TM analysis. Journal of Banking \& Finance, v. 1, n. 1, p. 29-54, 1977.

ALTMAN, E. I; HOTCHKISS, E. Corporate financial distress and bankruptcy: predict and avoid bankruptcy, analyze and invest in distressed debt. 3. ed. Hoboken, NJ: John Wiley \& Sons, Inc., 2006.

ALVES, S. L. Eficiência das operadoras de planos de saúde. Revista Brasileira de Risco e Seguro, v. 4, n. 8, p. 87-112, 2008.

ANS. Agência Nacional de Saúde. Anuário ANS: aspectos econômico-financeiros das operadoras de planos de saúde: 2006. Rio de Janeiro: Agência Nacional de Saúde Suplementar, 2007.

BARTON, S. L.; GORDON, P. J. Corporate strategy: useful perspective for the study of capital structure? The Academy of Management Review, v. 12, n. 1, p. 67-75, 1987.

BRAGA, R. Análise avançada do capital de giro. Caderno de Estudos, FIPECAFI, v. 3, 1991.

BRASIL, H. V. Posfácio. In: FLEURIET, M. J.;KEHDY, R.; BLANC, G. O Modelo Fleuriet: a dinâmica financeira das empresas brasileiras. Rio de Janeiro: Elsevier, 2003. Cap. Posfácio. p.165.

COHEN, J. Statistical power analysis for the behavioral sciences. 2. ed. Hillsdale, NJ: Lawrence Erlbaum Associates, 1988.

COLLINS, G. W. Analysis of working capital. The Accounting Review, v. 21, n. 4, p. 430441, 1946.

D'OLIVEIRA, N. V. L. C. Mercados de seguros: solvência, riscos e eficácia regulatória. Rio de Janeiro: Funenseg, 2006. 164 p.

FLEURIET, M. J. Fleuriet's rebuttal to “questioning Fleuriet's model of working capital management on empirical grounds”. SSRN Working Paper, 2005.

FLEURIET, M. J.; KEHDY, R.; BLANC, G. A Dinâmica financeira das empresas brasileiras. Belo Horizonte: Fundação Dom Cabral, 1978.

FLEURIET, M. J. O Modelo Fleuriet: a dinâmica financeira das empresas brasileiras. Belo Horizonte: Campus; Fundação Dom Cabral (FDC), 2003. 
FREUDENHEIM, M. Health care costs rise twice as much as inflation. New York Times. New York, NY, 2006.

GITMAN, L. J. Princípios de administração financeira. 10. ed. São Paulo: Addison Wesley, 2004.

GLINER, J. A.; MORGAN, G. A. Research methods in applied settings: an integrated approach to design and analysis. Mahwah, NJ: Lawrence Erlbaum Associates, 2000. 465 p.

GRICE, J. S.; INGRAMB, R. W. Tests of the generalizability of Altman's bankruptcy prediction model. Journal of Business Research, v. 54, n. 1, p. 53-61, 2001.

HOWARD, J. M. The Aftermath of HMO insolvency: considerations for providers. Annals of Health Law, v. 4, p. 87-116, 1995.

KIERNAN, J. K. A Model for working capital requirements and corporate liquidity management. Credit \& Financial Management Review, n. 3, 1999.

MARQUES, J. A. V. D. C.; BRAGA, R. Análise dinâmica do capital de giro: o modelo Fleuriet. Revista de Administração de Empresas, v. 35, n. 3, p. 49-63, 1995.

MEDEIROS, O. R. D. Questioning Fleuriet's Model of working capital management on empirical grounds. Social Science Electronic Publishing,. Rochester, USA: SSRN 2005.

MIZRUCHI, M. S.; STEARNS, L. B. A Longitudinal study of borrowing by large american corporations. Administrative Science Quarterly, v. 39, n. 1, p. 118-140, 1994.

PARK, C. Working capital and the operating cycle. The Accounting Review, v. 26, n. 3, p. 299-307, 1951.

RICHARDS, V. D.; LAUGHLIN, E. J. A. Cash conversion cycle approach to liquidity analysis. Financial Management, v. 9, n. 1, p. 32-38, 1980.

SHIN, H.-H.; SOENEN, L. Efficiency of working capital management and corporate profitability. Financial Practice and Education, v. 8, n. 2, p. 37-45, 1998.

SHULMAN, J.; COX, R. An Integrative approach to working capital management. Journal of Cash Management, p. 64-68, 1985.

SHULMAN, J.; DAMBOLENA, I. Analyzing corporate solvency. Journal of Cash Management, Sep./Oct. 1986, p. 64-67, 1986.

SMITH, K. V. Profitability versus liquidity tradeoffs in working capital management. In: Co., 1980.

Readings on the management of working capital. St Paul, MN: West Publishing 